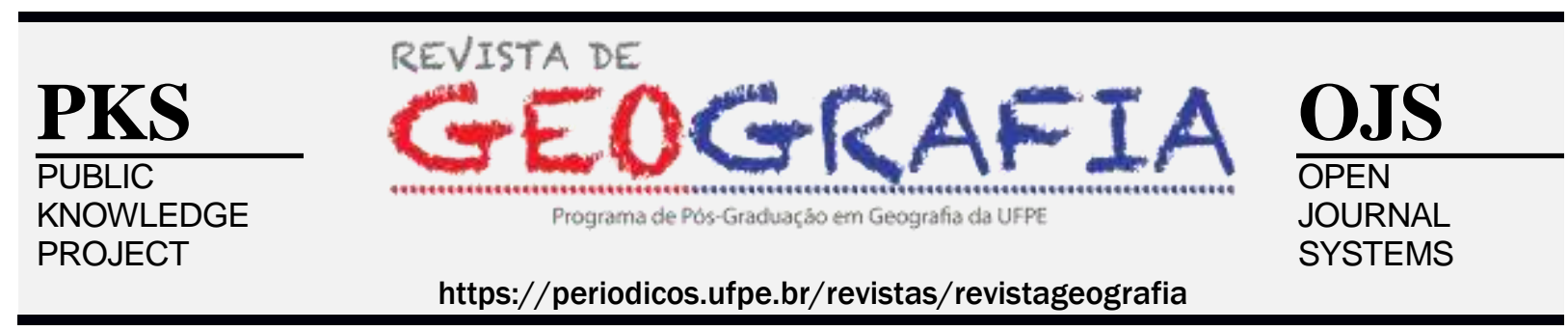

\title{
NECROPODER E NECROPOLÍTICA: UMA REFLEXÃO SOBRE O CONTEXTO ATUAL BRASILEIRO
}

\author{
Alcindo José de Sá ${ }^{1}$ \\ ${ }^{1}$ Professor e pesquisador do Programa de Pós-Graduação em Geografia/UFPE. E-mail: alcindo@ufpe.br
}

Artigo recebido em 19/12/2019 e aceito em 20/01/2020

\begin{abstract}
RESUMO
O presente ensaio trata de uma de discussão e análise sobre uma temática que, no período histórico atual, vem aflorando com bastante proeminência. Para tanto, iniciamos com um pequeno resgate do que seja o poder, no contexto do Estado-Nação moderno, ou seja, o poder como ente de capacidade de "controle e dominação sobre os homens e sobre as coisas", ou seja, sobre um território soberano, com leis e normas capazes de guiar tanto a zoés natural, os corpos nus do homem natural, quanto o bio político, o homem, democraticamente participativo e subjugado aos poderes estabelecidos.
\end{abstract}

Palavras-chave: Necropoder, Necropolítica, Geografia Política.

\section{NECROPOWER AND NECROPOLITICS: A REFLECTION ON THE CURRENT BRAZILIAN CONTEXT}

\begin{abstract}
The present essay deals with a discussion and analysis on a theme that, in the current historical period, has emerged quite prominently. To do so, we start with a small rescue of what power is, in the context of the modern nationstate, that is, power as an entity capable of "control and domination over men and things", that is, over a sovereign territory, with laws and norms capable of guiding both the natural zoés, the naked bodies of the natural man, and the bio-politician, the man, democratically participative and subjugated to the established powers.
\end{abstract}

Keywords: Necropower, Necropolitics, Political Geography. 
Começamos este ensaio buscando, em primeiro lugar, uma definição concisa sobre como podemos definir poder numa ótica geográfica. Para tanto, reportamo-nos a Claude Raffestin (1993, p. 52), quando o mesmo assevera que, uma explicação para este ente político/territorial é complexa, multifacetada, e de difícil definição. Para o referido autor isto se dá devido a sua face dúbia: um poder que não quer se mostrar, concomitante, mas, paradoxalmente, em muitos casos, obrigado a se tornar palpável e visível. "O primeiro é mais fácil de cercar porque se manifesta por intermédio dos aparelhos complexos que encerram o território, controlam a população e dominam os recursos. É o poder visível, maciço, identificável" [o Poder do Estado Nação com P maiúsculo]. Inspira perigo, desconfiança, já que sugere ameaça. Todavia, o supracitado autor também destaca que, ainda mais periculoso, é o poder invisível, pois este emana de todas as relações, ou seja, da multidimensionalidade e imanência de toda organização, ou sistema relacional [por exemplo, sindicatos, empresas, corporações financeiras, poderes paralelos ao Estado, enfim, poderes com o p minúsculo que envolvem dissimetrias de renda, informação e classe social]. Neste prisma, e embasando-se em Deleuze e Foucault, Raffestin (1993, p.56) frisa que onde há exercício do poder há um correspondente do exercício do saber. Assim, "a energia pode ser transformada em informação, portanto, em saber; a informação pode permitir a liberação de energia, portanto de força. $\mathrm{O}$ poder também é, nessas condições, um lugar da transmutação”, ou seja, de metarmofose, de mudança, inclusive de entropia. É por isso que Balandier (apud, RAFFESTIN, p.54) assinala: para "esta sociedade, o poder será definido como resultante da entropia [imprevisibilidade, incerteza] que a ameaça de desordem". Findando esse parágrafo-base conceitualmente, mencionamos Etzioni (apud RAFFESTIN, p.54-55), ao ressalvar que o poder de coerção embasa-se na aplicação de "sanções físicas", o poder remunerador "rémunérative" tem por base o "controle dos recursos materiais, sobre a destinação de salários ou de gratificações, enquanto o poder normativo se funda sobre a manipulação de recursos simbólicos...E, em outros termos, pode-se dizer que o poder, quanto aos poderes mobilizados, é definido por uma variável de energia e informação". Nesses termos, podemos dizer que o poder lastreia-se no trabalho. Este seria o veio básico e fonte e dois elementos seminais dinamizadores do mando: a energia e a informação. "O trabalho é a energia informada" e daí, "é admissível falar de resistência onde existe poder: resistência da matéria ou resistência do corpo social à transformação" (Rafesstin,1993, p.56). Nesse prisma, o poder tem como objetivo "o controle e dominação sobre 
os homens e sobre as coisas" e, assim, podemos resgatar o Poder da Geografia Política "tripartite" tradicional: a população organizada socialmente, dominando um território e seus recursos.

Nesta visão "clássica" do Poder, ou dos micro poderes, sobressai-se que estamos nos reportando à visão do Estado Moderno, significativo de uma superestrutura jurídica e política que embasa a infraestrutura econômica de inúmeras unidades produtivas, mercadológica e financeiras lhes dando suporte legislativo/normativo, bem como, se necessário, a legalidade repressiva, caso a entropia, a desordem venham lhes fustigar, ou seja, quando houver resistência do corpo social, ou a quebra da energia em informação e esta, em saber manipulado pelo capital dominante. Assim sendo, poder de coerção do referido Estado deságua, muitas vezes, em sanções físicas, como acima assinalado. Todavia, quando falamos de "corpo social", evidencia-se que estamos tratando de seres humanos, em interação social, sob a labuta de um sistema capitalista que tem mudado seus processos produtivos, bem como relações sociais de produção e ação do Estado de Direito e, consequentemente, de poderes, desde o seu alvorecer. Santos (1996) tem destacado a ascensão do capitalismo global, particularmente nas três últimas décadas, sob a égide do "meio técnico-científico-informacional”, propiciando a criação de um motor único, uma moeda única [muito embora com nomes novos e pretéritos], simbologias únicas com lastro no ship; no sistema informacional global em rede. Já Harvey (1993), no livro Condição Pós-Moderna, disseca os modelos de produção liberal no Século XIX, o modelo de produção Fordista e Fordista/Keunesiano, em especial no pós II Guerra Mundial, em muitos países da Europa e do mundo e o neoliberalismo no contexto do modo de produção capitalista atual. O mesmo se pergunta: é um mero reparo temporário ou como ressaltou Fukuiama, “o fim da história", em seu pleno êxito. Bauman (2001) em Modernidade Líquida, Vidas Desperdiçadas (2005), e em outros inúmeros trabalhos tem uma visão profundamente crítica, enxergando um capitalismo cada vez mais fragmentário, fugaz, tanto na produção quanto no consumo, criando crescentemente uma "cultura do lixo", "vidas para consumo" e um trabalho cada vez mais precarizado, já que vem se tornando subtrabalho, não-trabalho, criando semtetos, gente de rua, drogados, ou seja, niilistas forçados.

É no supracitado "novo contexto" que podemos situar o "corpo social" com corpos desprovidos, ou cada vez mais marginalizados do escopo social, visto que suas energias não são transformadas em informação e educação mediadas pelo trabalho. São homens “nus”, como trata Agamben (2004) e, assim, seres meramente biológicos, mas intencionalmente sob a mira 
do poder, Daí Mbembe (2018, p.09), em seu pequeno e denso ensaio, Necropolítica, advertir que a política [do Estado Moderno, ou Pós, como queiram], "privilegiou as teorias normativas da democracia e tornou o conceito de razão um dos elementos mais importantes tanto do projeto de modernidade quanto do território da soberania...A política, portanto, é definida duplamente: um projeto de autonomia e a realização de um acordo em uma coletividade mediante comunicação e reconhecimento. É isso, dizem-nos, que a diferencia da guerra”. Neste cadinho, o referido autor, alega que o nosso contexto territorial, inclusive onde se tornou o "lugar no qual se realizou a mais absoluta condicio inhumana que já se deu sobre a terra" [se referindo ao holocausto judeu], leva a sua preocupação não para uma formatação de uma soberania em que se privilegie um status de projeto por autonomia e acordo de harmonia social, mas a “instrumentalização generalizada da existência humana e a destruição material de corpos humanos e populações...Em vez de considerar a razão a verdade do sujeito, podemos olhar para outras categorias fundadoras menos abstratas e mais palpáveis, tais como a vida e a morte" (IDEM, pp. 10-11), visto que ambas, direta e indiretamente, estão envoltas nos processos produtivos e normativos, sejam como entes de deseconomias ou economias, ou seja, entropias ou não na esfera do poder. Por isso Bataille (apud Mbembe, 2018, p.14) frisa que "a vida além da utilidade...é o domínio da soberania", fato a denotar que o "soberano", ou soberanos, além de "vigiar e punir", como nos lembra Foucault, o corpo social produtivo também controla os corpos "nus", as vidas desperdiçadas, restolhos humanos de um capitalismo que passou a descartar parte substantiva do que foi a sua própria essência: o trabalho como energia informada, base da mais-valia relativa e absoluta e lastro de sua acumulação ampliada, como pioneiramente nos apontou Marx, no seu livro O Capital. Afinal, como o referido autor fez o alerta, o sistema de produção capitalista carecerá sempre de um exército de reserva, não importa se precarizado, proletarizado, descartado, ou simplesmente nu ou uberizado [grifo nosso]. Se, redundante, o mundo soberano do capital talvez esteja a apontar novos rumos.

Assim, nesse mundo globalizado (para muitos em processo de desglobalização, pelo menos politicamente), para (Mbembe, 2018, p.15), embasando-se em Bataille, "a soberania tem muitas configurações. Mas, em última análise, é a recusa de aceitar os limites a que o medo da morte teria submetido o sujeito. O mundo da soberania, Batalle argumenta, 'é o mundo no qual o limite da morte foi abandonado. A morte está presente nele, sua presença define esse mundo de violência, mas enquanto a morte está presente, está sempre lá apenas para ser negada, nunca para nada além disso. O soberano, conclui, 'é ele quem é, como se a morte não fosse...Não 
respeita os limites de identidade mais do que respeita os da morte, ou, ainda, esses limites são os mesmos; ele é a transgressão de todos esses limites’. Uma vez que o domínio natural da proibição inclui a morte, entre outras (por exemplo, sexualidade, sujeira, excrementos), a soberania exige que 'a força para violar a proibição de matar, embora verdadeira, estará sob condições que o consumo define"”. Assertivas duras e profundas, considerando que o Estado soberano, ao suprimir um dos seus fundamentos que era "a recusa de aceitar os limites a que o medo da morte teria submetido o sujeito", supõe-se que a morte, de forma barbarizada e animalesca, torna-se algo banal. Fato, como frisou Agamben (2004), comparável à morte de um Homo Sacer, um ser, no contexto jurídico do Império Romano, no qual a sua morte não tinha nenhum valor, seja como sacrifício aos Deuses, seja como significado à sociedade "laica". No linguajar pernambucano, e em especial ao recifense, uma "alma sebosa", que sequer deveria ter nascido; um lixo imprestável que deve e deveria ser dizimado, seja através das forças repressivas do Estado Soberano, ou através de sicários, matadores frios milicianos, já que são corpos "nus", desprovidos de almas piedosas e não "cidadãos de bem", ou seja, pessoas com a mínima formação de civilidade e valores morais. Enfim, seres que, na sua maioria, nasceram à margem da lei, desprovidos de inserção social e territorial (SÁ, 2013).

Todavia não devemos deixar de atentar que grande parte deste "corpo social", por pertencer, em especial, no contexto histórico atual, ao "refugo humano", não mais reciclável, fora da rede do consumo, implica, lebrando Mbembe $(2018$, p13) que "uma vez que o domínio natural da proibição inclui a morte, entre outras...a soberania exige que 'a força para violar a proibição de matar, embora verdadeira, estará sob condições que o consumo define'". E é por isso que a história presente esta prenhe de fatos que corroboram esta assertiva, seja, como já frisado, nos territórios micros, dominados pelos micropoderes paralelos (de "bandidos"1),

\footnotetext{
${ }^{1}$ Agamben (2004, pp.115-116) destaca que se faz, então, necessário reler desde o início "o mito da fundação da cidade moderna, de Hobbes a Rousseau. O Estado de natureza é, na verdade, um extado de exceção, em que a cidade se apresenta por um instante (que é ao mesmo tempo, intervalo cronológico e átimo intemporal) tamquam dissoluta. A fundação não é, portanto, um evento que se cumpre de uma vez por todas in illo tempore, mas é continuamente operante no estado cível na forma de decisão soberana. Esta, por outro lado, refere-se imediatamente à vida (e não à livre vontade) dos cidadãos, que surge, assim, como elemento político originário, o Urphänopmenon da política: mas esta vida não é simplesmente a vida natural reprodutiva, a zoé dos gregos, nem o bíos, uma forma de vida qualificada; é, sobretudo, a vida nua do homo sacer e do wargus, zona de indiferença e de trânsito entre o homem e a fera, a natureza e a cultura". Ainda o referido autor acrescenta: "a relação de exceção é uma relação de bando. Aquele que foi banido não é, na verdade, simplesmente posto fora da lei e indiferente a esta, mas é abandonado por ela, ou seja, exposto e colocado em risco no limiar em que a vida e direito, externo e interno, se confundem. Dele, não é literalmente possível dizer que esteja fora ou dentro do ordenamento (por isso, em sua origem, in bando, a bandono, e bandito quer dizer tanto excluído, posto de lado 'quanto aberto a todos, livre', como em mensa bandita e a redina bandita). É neste sentido que o paradoxo da soberania pode assumir a forma: 'não existe um fora da lei'. A relação originária da lei com a vida não é a aplicação,
} 
quanto nos territórios macros dos Estados Nações, sob a égide do capital global manipulado pelas grandes corporações e pelo capital financeiro global, gerenciado por órgãos "globais" como FMI, Banco Mundial, etc.. Neste último caso, fica bem patente a força bruta, a "força para violar o poder de matar" do Estado Equatoriano sob os seus cidadãos, em período recente, já que os mesmos ficaram desprovidos de um poder de consumo, em especial dos combustíveis majorados, imposto pelo Estado soberano sob os ditames do FMI. Já que no que toca aos micropoderes, ficam bem estampado em muitos países, em especial no Brasil com o Governo Eduardo Bolsonaro, nas Filipinas com Rodrigo Duterte, Turquia com Recep Edogan, etc., com o crescente poder das milícias, manipulando o cotidiano de consumo básico das pessoas em determinados territórios, bem como chegando ao extremo de ditar Estado de exceção no próprio Estado Nacional ditador de exceções; poderes, inclusive, que executam representantes do poder do Estado Nação autorizado a usar o Exceptio. Neste ínterim, não podemos deixar de destacar o legislativo completamente financiado pelo poder econômico de corporações agrícolas, industriais e financeiras, legislando por pressões de lobbes de cada segmento em seus benefícios , em detrimento da formatação e planejamento de um Estado mínimo de bem-estar social. É um Estado, como afirma Agamben (2004), que se aplica se desaplicando, ou seja, tem por base preceitos constitucionais de assistência mínima ao cidadão, mas na práxis, os relega. Portanto, em nome de um estado enxuto e equilibrado, o Estado de Excetio alega não ter condições de prover os desvalidos, e o mercado advoga que somente a competição e a competitividade, podem absorver a mão de obra excedente. Já o Poder Judiciário, em certa medida, apenas executa os ditames normativos do executivo e legislativo. Neste sentido fica patente que por conta da falta desses suportes do Estado político/ jurídico e do mercado, em particular no Brasil, muitas mortes intencionais e pseudo invisíveis pela pobreza, ou seja, pela falta de saneamento (a proliferação da dengue, da febre amarela, etc.), pelo péssimo atendimento hospitalar e a total carência educacional, fazem parte da "força para violar a proibição de matar" do Estado Soberano.

Neste contexto, cabe acrescentar algo que escrevemos, em passado recente, quando dizíamos que com o advento da racionalidade instrumental globalista, o mundo da linguagem, no dizer de [Bifo,2005], dominado pelo semiocapital sem vida, sem o corpo erótico que se

mas o abandono. A potência insuperável do nómos, a sua originária 'força da lei', é que ele mantém a vida em seu bando abandonando-a". Enfim, no nosso mundo líquido e cada vez mais fluido (BAUMAN, 2014), de leis cada vez mais "flexíveis", não existe um ser fora da lei, mas a relação originária da lei com a sua vida, não é a aplicação formal da mesma, mas o abandono. Daí a existência de tantos "bandidos", organizando suas próprias "leis". 
pensa em nós muito além da vida nua, de uma vida social assomada em parâmetros civilizados, de tolerância entre estranhos, passou a triunfar (SÁ, 2013). Neste sentido, “a política, na execução da tarefa metafísica que a levou assumir sempre mais a forma de uma biolítica, não conseguiu construir a articulação entre zoé (natureza) e bíos (política), entre voz e linguagem, que deveria recompor a fratura. A vida nua continua presa a ela, sob a forma da exceção, isto é, de alguma coisa que é incluída somente através de uma exclusão. Como é possível 'politizar' a 'doçura narural' da zoé? E antes de tudo, tem ela verdadeira necessidade de ser politizada ou o político já está contido nela como o seu núcleo mais precioso? A biopolítica do totalitarismo moderno de um lado, a sociedade de consumo e do hedonismo de massa de outro constituem certamente, cada uma a seu modo, uma resposta a estas perguntas. Até que, todavia uma política integramente nova - ou seja, não mais fundada sobre a exceptio da vida nua - não se se apresente, toda teoria e toda praxe permanecerão aprisionadas em um beco sem saídas, e o 'belo dia' da vida só obterá cidadania política através do sangue e da morte ou na perfeita insensatez a que a condena a sociedade do espetáculo" (AGAMMBEN,2014, pp.18-19, in SÁ). E dando continuidade, escrevíamos: como nos alerta Castoriades (2002), se a sociedade (em particular a Ocidental) conseguiu se "civilizar" duas ou três escalas espaço/temporais ao longo do seu processo histórico, porque, nesse tempo presente, ela não consegue "politizar a doçura natural da zoé"?; criar um espaço com mais conteúdo de cidadania? Cremos que Agamben (2004) nos vislumbra um caminho: como já ilustrado, a zoé já nasce, intencionalmente, pelos poderes visíveis e invisíveis dominantes, como exceptio feitores de vidas nuas, ou porque também não dizer, nulas, considerando hoje, como nos assevera Bauman (2005), tanto a insensibilidade do Estado Nacional de Exceção quanto a indiferença do mercado e, nesse beco sem saída, ou melhor, nesse beco com uma só saída (a mercadológica), o belo dia da vida só obterá “cidadania" política por intermédio do sangue e da morte , no contexto da perfeita insensatez da ideologia globalista, a sociedade do semiocapital "do espetáculo" descartante de corpos de vidas nuas dotadas apenas de zoé natural. Por isso, essa mesma sociedade do espetáculo espetaculiza comercialmente as violências mais selvagens (em especial em países onde os Estados paralelos de exceptio dominam vidas e territórios, com as suas organizações criminosas sanguinárias e impiedosas, como as tradicionais CV, PCC, etc.no Brasil, com ramificações já em quase todo o território nacional), como barbárie, mas, na verdade, camuflando, transmitindo como simulacro uma realidade que é de fato parte da biopolítica do totalitarismo Estatal/mercadológico do mundo dito pós-moderno. Não se trata aqui de defender a barbárie 
em que se encontram a sociedade brasileira e outras alhures, como uma nova dialética de luta de classes (mesmo porque definir classe social nessa sociedade de alienação midiática e de redes comunicacionais, de um trabalho extremo de precarização, ou de um cognitariado alçado a "pequenos burgueses", além dos capitalistas tradicionais de toda sorte, é algo complexo até para sociólogos), como forma de conformismo e rendição a esta sociedade do consumo, do niilismo, do hedonismo de massa, excludente e cruel. Mas é também fato inegável que ações racionais, ou mesmo atabalhoadas das vidas nuas do exceptio político paralelo, dos homo sacer, por mais cruéis ou desumanas que possam parecer, ou aparecerem no espetáculo do semiocapital, que banham de sangue e de morte com mais intensidade, têm mobilizado os contrapoderes, os poderes com letra minúscula do exceptio soberano paralelo à criação de cidadania política e inserção territorial, através dos seus sangues e morte no período histórico atual (SÁ, 2013, p108). Como prova cabal, segundo dados do CIMI (Conselho Indigenista Missionário), foram mortos, em 1918, no território brasileiro 135 indígenas na luta por seus espaços de vida ${ }^{2}$. Já o IPEA destaca que, com 65 mil mortes, homicídios batem record no país em 1017 [segundo levantamentos mais recentes, nesses dois últimos anos houve uma pequena diminuição] e os jovens negros têm sido suas maiores vítimas. "Dentro da questão racial, estudo revela que para cada não negro (branco, indígena, amarelo, segundo critério de autoatribuição usado pelo IBGE) morto no Brasil, quase 3 negros (pretos e pardos) foram assassinados. Esse cenário vem piorando ao longo da última década; enquanto o índice de homicídios de não negros aumentou $3,3 \%$ de 2007 a 2017 , o de negros aumentou $33,1 \%$ " 3 .

Tendo como parâmetro o pequeno quadro empírico supracitado, da realidade brasileira, atentemos as falas de Mbembe (2018, pp.16-19), quando este relaciona a noção de biopoder de Foucault a dois outros conceitos: "o estado de exceção e o estado de sítio". O Mesmo examina "essas trajetórias pelas quais o estado de exceção e a relação de inimizade tornaramse a base normativa do direito de matar. Em tais instâncias, o poder (e não necessariamente o poder estatal) continuamente se refere e apela a exceção, à emergência e a noção ficcional do inimigo...o biopoder parece funcionar mediante a divisão entre as pessoas que devem viver e as que devem morrer...Que a 'raça (ou na verdade, o 'racismo' tenha um lugar proeminente na nacionalidade própria do biopoder é inteiramente justificável...Arendt localiza suas raízes na

\footnotetext{
2 https://g1.globo.com/natureza/noticia/2019/09/24/numero-de-assassinatos-de-indigenas-cresce-20percent-nobrasil-em-2018-aponta-relatorio.ghtml

${ }^{3}$ http://www.ipea.gov.br/atlasviolencia/arquivos/downloads/6537-atlas2019.pdf
} 
experiência demolidora da alteridade e sugere que a política de raça, em última análise, está relacionada coma política da morte. Com efeito, em termos foucaultianos, racismo é acima de tudo uma tecnologia destinada a permitir o exercício do biopoder ' este velho direito soberano de matar"'. Claro que tudo isso esta associado a ação do capital em todas as suas instâncias e suas práticas políticas ocidentais (agora espraiadas pelo mundo), envolvendo cada vez mais migrantes e suas variantes de raça e gênero. É nesse contexto que podemos encaixar os zoés, os corpos nus (na sua maioria negra) cada vez mais marginalizados, no território brasileiro e sendo os mesmos dizimados, já que no, nosso biopoder, estão situados para morrerem, no contexto do direito soberano de matar. Não por acaso, o Governador do Rio de Janeiro Wilson Witzel, advogou, que os traficantes de armas poderiam ser explodidos por mísseis e que deveria ser construído uma prisão nos moldes de Guatánamo; também distribuir fuzis para a população para que esta ajudasse a exterminar os indesejáveis. O certo é que o referido governador tem usado, mesmo que de forma camuflada, um verdadeiro estado de "sítio" em certos territórios "periféricos", já que o Estado policial tem adentrado os mesmos, sob o argumento de combate as organizações criminosas (que também existem de fato), todavia sem proteção a população civil, inclusive matando crianças, na sua maioria, negra, no fogo cruzado de balas "perdidas" e, assim, temos que comungar com Arendt, quanto esta frisa que política de raça (no caso da cidade do Rio de Janeiro com as suas favelas e morros dominados por população, majoritariamente negra e pobre), está relacionada com a política de morte. Já no plano Federal, temos o projeto de combate a criminalidade, em que uma de suas normativas é a de dar poderes de matar a qualquer policial que se ache vulnerável a uma suspeição bandida.

Assim, repetimos, "nesse embate o poder (e não necessariamente o poder estatal) continuamente se refere e apela a exceção, à emergência e a noção ficcional do inimigo...o biopoder parece funcionar mediante a divisão entre as pessoas que devem viver e as que devem morrer”. O verdadeiro mundo do salve-se quem puder. E é nesse contexto que se evidencia o terror convertido "numa forma de marcar a aberração no corpo político, e a política é lida tanto como força móvel da razão quanto como a tentativa errática de criar um espaço em que o 'erro' seria minimizado, a verdade, reforçada, e o inimigo, eliminado” (MBEMBE, 2018, p.23). Reforçando: numa entrevista à jornalista Roberta Pennafort, do Jornal O Estado de São Paulo, em 01/11/2018, o então Governador eleito do Rio Wilson Witzel falou: "a polícia vai mirar na cabecinha e...fogo". Em parte da entrevista à profissional, questiona se ele defende a "excludente de ilicitude" para policiais em serviço, tendo o mesmo como resposta: "se for um 
ato em confronto, em que o policial está acobertado por uma excludente de ilicititude, não é homicídio, é morte em combate...É auto de resistência e arquivo. O ato é lícito”, já que está no código penal. Seguindo com a entrevista, a mesma também indaga se caso ele desse autorização para execução (como ocorreu recentemente com um sequestro de um ônibus na ponte Rio/Niterói) e o policial fosse processado, “a responsabilidade não cai no seu colo?...não vai cair no meu colo nada. Vai cair no Estado. O Estado tem de entender que tipo de segurança pública quer". Então a jornalista provoca: então "da polícia o cidadão espera a conduta correta; do bandido, não...”. De pronto o Governador responde: “o correto é matar bandido de fuzil. A polícia vai fazer o correto: vai mirar na cabecinha e...fogo! Para não ter erro"4, muito embora o portal G1 da globo em 20/10/2019 alegue que nunca se matou tanto policial quanto este ano ${ }^{5}$. Assim sendo, fica mais que notório que as assertivas de Mbembe (2018) têm plena realização territorial empírica, pois este quadro de referência no Rio de Janeiro [e praticamente em todo o Brasil, pois o governador Wilson Witzel, apenas expressou o que a maioria dos governadores do Brasil pensa, independente das linhagens políticas] prova que os poderes de matar, tanto dos "bandidos", das organizações criminosas, quanto os poderes do Estado são insaciáveis, eventos que denotam, digamos, uma biopolítica também pasicopata, sempre à espreita de uma presa, nem que seja de um inimigo ainda ficcional, neste mundo dominado por um processo produtivo tecnológico/informacional e comunicacional pautado na razão da indiferença [grifo nosso].

Podemos vislumbrar o acima supracitado, também na proposta do Projeto Anticorrupção e Antiviolência do Ministro Sérgio Moro, quando o mesmo prevê que, "no julgamento de crimes em legítima defesa, "o juiz poderá reduzir a pena até a metade ou deixar de aplicá-la se o excesso decorrer de escusável medo, surpresa ou violenta emoção". O caso só será julgado se houver excesso - por exemplo, número muito alto de tiros. Já no caso de policiais em serviço, a proposta deixa mais clara quais situações podem ser consideradas ações de defesa. O texto permite livrar de penas o agente policial ou o agente de segurança pública que matar alguém em serviço em situação de "conflito armado ou em risco iminente de conflito armado" e para prevenir "injusta e iminente agressão a direito seu ou de outrem" agressão ou risco de agressão a reféns. Ou o agente que "previne agressão ou risco de agressão à vítima mantida refém durante a prática de crimes". Há que ressaltar que no Projeto do Ministro Sérgio

\footnotetext{
4 https://politica.estadao.com.br/noticias/eleicoes,a-policia-vai-mirar-na-cabecinha-e-fogo-diz-novo-governadordo-rio,70002578109

5 https://g1.globo.com/jornal-nacional/noticia/2019/09/20/no-rio-numero-de-mortes-por-policiais-em-2019-erecorde.ghtml
} 
Moro o "excludente de ilicititude" não foi aprovado pelo Congresso, muito embora a matança dos zoés continuem intensas, independente dessa cláusula. A lei atual "define legítima defesa como a situação em que o policial, 'usando moderadamente dos meios necessários, repele injusta agressão, atual ou iminente, a direito seu ou de outrem'. Na prática, não responderiam a processo criminal policiais em serviço que matarem alguém em razão de confronto ou pessoas comuns que apresentarem provas de que a morte ocorreu em legítima defesa" ${ }^{\text {. }}$. Ou seja, fica evidente que a força do biopoder do estado de exceptio pode, em caso de "escusável medo, surpresa ou violenta emoção" penalizar o agente agressor "defensivo", ou mesmo não penalizar o agente policial ou o agente de segurança pública, em especial se os mesmos matarem um zoé, um bandido que se encontre no meio de um conflito armado ou em risco de conflito com os “agentes policiais da lei”. Assim sendo, “a política [ou abiopolítica] é lida tanto como força móvel da razão quanto como a tentativa errática de criar um espaço em que o 'erro' seria minimizado, a verdade, reforçada, e o inimigo, eliminado", como asseverado acima. Ou seja, a lei evidencia-se hoje móvel e minimizadora do erro [no caso, uma matança errática], pois o que importa é a verdade cada vez mais palpável, reforçada, da existência de um inimigo que precisa ser eliminado.

Mas o certo é que, apesar dos índices criminais terem apontado uma pequena queda em 2019, continuamos ainda a ser um dos países onde mais se mata no mundo. Portanto, considerando, em especial levantamentos de dados do IPEA e Fórum Brasileiro de Segurança Pública, o número de mortes, anualmente no Brasil, é 30 vezes maior do que na Europa inteira; mais de meio milhão de pessoas foram assassinadas na última década (553 mil), isto é, 153 mortes por dia, e pela primeira vez na história do país, em 2016 o número de homicídios no Brasil superou a casa dos $60 \mathrm{mil}$, mais precisamente 62. 517 crimes de mortes letais e intencionais (CVLI), valor correspondente à soma do numerário de 154 países, segundo o referido IPEA e o Instituto Igarapé ${ }^{7}$. Com esses índices, registram-se, no país, 160 assassinatos por dia, ou seja, quase sete (já os dados de 2016 são 9 e os atuais - vide abaixo - sete) assassinatos por hora, de acordo com o $9^{\circ}$ Anuário Brasileiro de Segurança. "O Brasil ostenta

\footnotetext{
${ }^{6}$ https://g1.globo.com/politica/noticia/2019/02/04/moro-apresenta-a-governadores-projeto-anticrime-com-14alteracoes-em-leis.ghtml

7 https://oglobo.globo.com/brasil/atlas-da-violencia-2018-brasil-tem-taxa-de-homicidio-30-vezes-maior-do-queeuropa-22747176.
} 
taxas tão altas há tantos anos que se pode falar em uma violência endêmica, e não epidêmica. É um problema grave e crônico. Nós concentramos 2,8\% da população do mundo e $11 \%$ dos homicídios. Somos um país extremamente violento", afirma a socióloga Samira Bueno, diretora-executiva do Fórum Brasileiro de Segurança Pública, organização responsável pela elaboração do anuário. Corroborando essa catástrofe, o periódico Brasil de Fato, estampa que entre 2004 a 2007, no Iraque, país oficialmente em guerra, morreram 76.266, no Sudão, 12.719, no Afeganistão 12417 e na Colômbia, 11.833, já no Brasil, nessa mesma escala de tempo, o número de mortes atingiu o patamar de 147.333, ou seja, um número superior a 34.098 ao dos quatro países em conflito ${ }^{8}$.

Ainda de forma demasiadamente perspicaz sobre as diversas formas de supressão das zoés, dos corpos nus, desprovidos de pertencimento civilizatório, de cidadania, o mesmo aprofunda ainda mais os espaços discricionários que os mesmos vivem a se submeter, diante das diversas escalas de poder, em especial o poder do capital "liquido", "fluido" (BAUMAN,2001) que escorre sobre diversas redes legais e ilegais que o mesmo se exerce, ou facilita seu exercício, seja sob a tutela do Estado-nação ou não. Para tanto Mbembe (2018, pp. 32-35) faz um resgate lúcido do papel da formação do Estado moderno europeu e sua ordem jurídica Jus publicum europeaum, em que este "postulava a igualdade jurídica de todos os Estados. Essa igualdade se aplicava especialmente ao 'direito de fazer a guerra' (de tomar a vida)". Assim, esse direito significava, ao mesmo tempo, que o poder de matar ou negociar eram direito do Estado, no contexto dos seus limites fronteiriços sem afrontar os demais. "Por outro lado, o Estado se comprometeria a 'civilizar' os modos de matar e atribuir objetivos racionais ao próprio ato de matar". Nesta perspectiva, "no pensamento filosófico moderno assim como na prática e no imaginário político europeu, a colônia representa o lugar em que a soberania consiste fundamentalmente no exercício de um poder à margem da lei (ab legibus solutus) e no qual a 'paz' tende a assumir o rosto de uma 'guerra sem fim'...Como tal as colônias são o local por excelência em que os controles e as garantias de ordem judicial podem ser suspensos - a zona em que a violência do Estado de exceção supostamente opera a serviço da 'civilização"”. E buscando uma explicitação, aliás, brilhantemente geográfica, Mbembe (2018, pp. 38-39), assevera: “A 'ocupação colonial' em si era uma questão de apreensão,

\footnotetext{
${ }^{8}$ http://www.brasildefato.com.br/node/12564
} 
demarcação e afirmação do controle físico e geográfico - inscrever sobre um terreno um novo conjunto de relações sociais e espaciais. Essa inscrição de novas relações ('territorialização') foi, enfim, equivalente à produção de fronteiras e hierarquias, zonas e enclaves; a subversão dos regimes de propriedade existentes; a classificação das pessoas de acordo com diferentes categorias; extração de recursos; e, finalmente, a produção de uma ampla reserva de imaginários culturais". E no contexto dessa modernidade, a África do Sul como Estado-nação sob a inspiração do Jus publicum europeaum e do regime do apartheid, considerava o "distrito" sua estrutura básica e os bantustões (homelands) territórios rurais nos quais fixavam-se a mão de obra migrante regulada e a urbanização, enfim, sob controle. Citando Belenda Bozzoli, Mbembe (2018, p.39) expressa que o "distrito era particularmente um lugar em que 'opressão e pobreza severas foram experimentadas com base na raça e classe social”. Para o referido autor $(\mathrm{p}, 41)$, a soberania moderna [grifo nosso] é “a capacidade de definir quem importa e quem não importa, quem é 'descartável' e quem não é” e neste contexto, as ocupações mais recentes, diferentemente da moderna, com seu arcabouço disciplinar e biopolítico, aflora com mais avidez a necropolítica.

Ora, considerando o período colonial, com o do Estado Moderno, tanto na África quanto em outros continentes, a disciplina e biopolítica, os corpos nus monitorados pelas leis e normas disciplinares, sempre se caracterizaram também, sob o imaginário político europeu. Portanto, a colônia e o Estado representaram sempre "o lugar em que a soberania consiste fundamentalmente no exercício de um poder à margem da lei (ab legibus solutus) e no qual a 'paz' tende a assumir o rosto de uma 'guerra sem fim'”. E é nesse contexto que se encontra a repressão de raça e de classe que se abateu com toda truculência e massacres, em especial na África do Sul, como colônia e através apartheid sob a égide do Estado Nação "Moderno", guiado politicamente por minorias brancas. Neste interim, enxergamos esses eventos como prenúncio do que hoje o próprio Mbembe define como necropolítica. Todavia, o referido autor, a encaixa melhor, considerando a "ocupação contemporânea da Palestina". Nesse território, Israel subtrai da nação palestina não só sua identidade, como também legitimidade das suas autoridades, em nome de seu direito, em parte, divino de existir (não podemos esquecer também que Israel é estratégico na Geopolítica dos Estados Unidos). Assim, "violência e soberania, nesse caso, reivindicam um fundamento divino: a qualidade do povo é forjada pela adoração de uma divindade mítica, e a identidade nacional é imaginada como identidade contra o outro, contra outras divindades [Alá e o Deus de Abraão, Izaque e Jacó]...Em consequência , a 
violência colonial [pós-moderna, grifo nosso] e a ocupação se apoiam no terror sagrado de verdade e de exclusividade (expulsão em massa, reassentamento de pessoas 'apátridas' em campos de refugiados, estabelecimento de novas colônias), Por trás do terror sagrado semita, a exumação constante de ossadas desaparecidas; a permanente lembrança de um corpo rasgado em mil pedaços e irreconhecível; os limites, ou melhor, a impossibilidade de representação de um crime 'absoluto', uma morte indizível: o terror do holocausto...Nessas circunstâncias, a ocupação colonial não equivale apenas ao controle, à vigilância e à separação, mas também a reclusão (MBEMBE, 2018, pp : 42-43). Considerando esta nova/velha contemporaneidade, vislumbramos, diante de uma crescente literatura sobre o descolonialismo, como desprovida de grandes fundamentos empíricos; enxergamos muito mais cum mundo em profundo processo de uma recolonização sob o ab legibus solutus, lastreado no imaginário político europeu, da ordem jurídica Jus publicum europeaum. Visões descolonialistas são muito importantes como utopias, como o tão rebatido discurso do novo constitucionalismo Latino Americano, ensaiado na Bolívia e alhures, países, hoje, submetidos a mais feroz pressão jurídica, militar e normatva globalista técnica/científca/informacional e financista gestadas nos "laboratórios" de Universidades Americanas e no FBI, a exemplo das famosa Lawfares para forjarem e condenarem líderes com apelo popular, bem como suprimir territórios com pendores de relações sociais e produtivas não totalmente subjugados ao mercado.

Por isso, ancorando-nos ainda em Mbembe (2018, pp. 52-54) e base de inspiração desse ensaio, vale acolhermos seus lúcidos escritos, sob a inspiração de Bauman, quando menciona que "esta nova era é o da mobilidade global. Uma de suas características é que as operações militares e o exercício do direito de matar já não constituem o monopólio exclusivo do Estado, e o 'exército regular' já não é o único meio de executar essas funções. A afirmação de uma autoridade suprema em um determinado espaço político não se dá facilmente. Em vez disso emerge um mosaico de direitos de governar incompletos e sobrepostos, disfarçados e emaranhados, nos quais sobejam diferentes instâncias jurídicas de facto geograficamente entrelaçadas, e nas quais abundam fidelidades plurais, suseranias assimétricas. Nessa organização heterônoma de direitos territoriais e reivindicações, faz pouco sentido insistir na distinção entre os campos políticos 'internos' e 'externos', separados por limites claramente demarcados." São assertivas que, ao nosso ver corroboram nossa tese de um processo neocolonial pós-moderno, no qual, tendo o poder globalista monitorando uma nova geopolítica calcada nos Estados nacionais fragilizados por questões étnicas, religiosas, de classes, tendo 
seus centros econômicos "neoimperiais", como EUA, China, Rússia, EU, a dominarem e "manipularem milícias urbanas, exércitos privados, exércitos de senhores regionais, segurança privada e exércitos de Estado que proclamam, o direito de exercer violência de matar...cada vez mais, a maioria dos exércitos é composta de soldados-cidadãos, crianças-soldados, mercenários e corsários...organizações difusas e polimorfas, as máquina de guerras se caracterizam por sua capacidade de metamorfose. Sua relação com o espaço é móvel”.

Neste contexto, como podemos contextualizar e caracterizar a Guerra na Síria? Justamente a corroboração de tais assertivas. Tendo seu conflito civil, incialmente, como protesto no âmbito da primavera árabe contra o governo de Bashar Al-Assad, no início dos anos 2000, o movimento descamba, posteriormente, para uma feroz guerra civil, tendo como primeiro grupo opositor a Assad o Exército Livre da Síria (ELS), uma dissidência do exército nacional. Posteriormente, por interesses geopolíticos globais, Rússia, Irã e milicianos xiitas, passaram apoiar o supracitado presidente, já que a Rússia sempre cobiçou acesso comercial via Mediterrâneo e Irã e milicianos xiitas se atritam com a Arábia Saudita, país que mantém laços estreitos com os Estados Unidos militarmente e comercialmente, já que é o maior produtor e exportador de petróleo, além de possuir a maior reserva do referido minério. Além disso, os EUA ambiciona a feitura de um canal de transporte pela área em conflito, que minimizaria custos e riscos, em especial, evitando o Estreito de Ormuz. Nesse redemoinho de conflitos, não podemos esquecer os Kurdos, com apoio Ianque e inimigos da Turquia, nem o aparecimento do EI (Estado Islâmico), grupo Jhadista que despontou após a guerra do Iraque. Enfim, se destacam como rebeldes milicianos mais importantes, financiados pelos EUA, Arábia Saudita, etc. o Jaysh al Islam, o ELS e o Ahrar al Sham. O certo é que o conflito continua, obrigando 65 milhões de pessoas a deixarem suas moradias. Afora centenas de milhares de mortes, 6 milhões obrigadas a deixarem suas casas e outros 5,5 milhões suplicarem refúgio, uma verdadeira diáspora mundo afora (REVISTA GALILEU, 30/09/2019). Porque falamos em Estados neocolonizados pós-modernos? Visto o relato acima, mas poderíamos também agregar a destruição do Estado Líbio de Kadafi, o Iraque de Husseim, são hoje entes mediadores, organizações difusas e polimorfas, territorialmente móveis, com exércitos constituídos por "soldados-cidadãos, crianças-soldados [tão presente no recrutamento do Estado Islâmico], mercenários e corsários, muitos deles recrutados no próprio seio de Estados europeus ou não. Enfim, sob a batuta dos velhos e emergentes impérios globais, repetimos, forjam "um mosaico de direitos de governar incompletos e sobrepostos, disfarçados e emaranhados, nos quais 
sobejam diferentes instâncias jurídicas de facto geograficamente entrelaçadas, e nas quais abundam fidelidades plurais, suseranias assimétricas. Nessa organização herônoma de direitos territoriais e reivindicações, faz pouco sentido insistir na distinção entre os campos políticos 'internos' e 'externos', separados por limites claramente demarcados” (IDEM, p.54), tendo como mote a flexibilidade crescente do poder de matar; mortes líquidas, fluidas de corpos nus, de zoés em um mundo cada vez mais cravado de "vidas desperdiçadas", lixos humanos não mais recicláveis por uma economia crescentemente racional, matematicista e tecnicista (BAUMAN, 2005), na qual o exército de reserva agora é submetido a um enredo pautado no necropoder e na necropolítica.

Para finalizar este ensaio, não podemos deixar de destacar, como já frisado ao longo do texto, nossa organização política heterônoma de "direitos territoriais e reinvindicações". Em trabalho recente, Sá (2016), intitulado Geocultura Política Pós-Moderna: limites e fronteiras em questão, assim como Mbembe (2018), ressaltamos que o nascimento e a feitura do Estado Moderno como um ente sempre em fazimento, sempre foram dotadas de contradições e conflitos. Isto, porque, sua base constitucional econômica/territorial sempre obedeceu uma lógica dissimétrica; da colônia a configuração mimética do Estado nacional europeu, prevaleceu e prevalece a ordem escravocrata, hoje de forma dissimulada. Ou seja, as várias escalas organizações (do Estado a sua residência, quarto) como sistemas sintagmáticos, signos visíveis e palpáveis ou não, frutos de programas elaborados por energias, fruto do trabalho metamorfoseado em informação e desta em códigos, no Brasil constitui-se sempre por fidelidades plurais, suseranias assimétricas, nas quais os limites entre o externo e o interno se imbricam, agora sob a égide de uma necropolítica e um necropoder devastador. É sobejamente conhecida a grande dimensão do trabalho escravo formal ou não em todo o território nacional, em quase todas as atividades econômicas. Nos setores agropecuários, mineradores, de tecelagem etc. Trabalhos desumanos que alimentam um capitalismo no qual o mercado é indiferente aos contextos de super exploração e o Estado se exime, em grande medida, alegando carência de recursos para minorar o suplício desses desvalidos. No que respeita ao território indígena no espaço brasileiro, temos uma vasta literatura sobre o extermínio de nações sob o peso da difusão da avidez do capital sobre nações indefesas, já que as mesmas são obrigadas a se submeterem a "um mosaico de direitos de governar incompletos e sobrepostos, disfarçados e emaranhados, nos quais sobejam diferentes instâncias jurídicas de facto geograficamente entrelaçadas, e nas quais abundam fidelidades plurais, suseranias assimétricas”. Podemos, nesse 
caso, indagar: que poderes de gestão e governança têm a Fundação Nacional do Índio frente a Madereiros, Garimpeiros, grileiros, com suas "fidelidades plurais", em meio a suseranias indígenas frágeis e assimétricas? Para Mbembe (2018, p.57), “a concentração de atividades relacionadas a extração de recursos valiosos em torno desses enclaves tem, por sua vez, convertido esses enclaves em espaços privilegiados de guerra e de morte. A própria guerra é alimentada pelo crescimento das vendas dos produtos extraídos"

Os referidos direitos de governar incompletos e sobrepostos se acirram ainda mais, ao tratarmos do crime organizado, hoje constituído por organizações com seus códigos sintagmáticos bem estruturados como necropoder "paralelo", com suas "normativas" de criação territorial de redes, nós, e espaços contíguos de consumo psicotrópico ou também de contrabando. Como frisa Bauman (2004), "o poder de excluir não seria um marco de soberania se o poder do soberano não tivesse se unido ao território...Em qualquer época as terras de fronteira foram conhecidas ao mesmo tempo como fatores de deslocamento e unidade de reciclagem dos deslocados. Nada mais pode se esperar de sua nova variedade global, exceto, é claro, a nova escala planetária de produção e reciclagem de problemas" e queiramos ou não, o "poder soberano do narcotráfico/contrabando" [grifo nosso], ou do crime organizado, quase sempre alinhados, têm se unido aos territórios, como fonte, em parte, de reciclagem de problemas e busca de soluções", como o modus operandis dos produtos narcóticos ou não, estratégia de montagem de redes para escoamento através dos mesmos, internacionais e nacionais, lavagem de dinheiro, "administração" de conflitos entre facções, considerando as "fidelidades plurais", PCC, CV e outras infinidades que se proliferam e se disseminam no território brasileiro com seus nós em São Paulo, Rio de Janeiro e, agora, seus "sub nós", como os de Manaus, Belém, Fortaleza, Natal, só para mencionar alguns. Assim, como bem assevera Mbembe (2018, pp. 57-58), "na maioria dos lugares, o colapso das instituições políticas formais sob a pressão da violência tende a conduzir à formação de economias de milícia. Máquinas de guerra (nesse caso, milícias ou movimento rebeldes) tornam-se rapidamente mecanismos predadores extremamente organizados, que taxam territórios e as populações que os ocupam e se baseiam numa variedade de redes transnacionais e diásporas que os proveem com apoio material e financeiro". Essa pauta está na ordem do dia dos nossos "podres" e pobres poderes, nos quais suas capacidades de governar denotam-se incompletas e sobrepostas, disfarçadas e emaranhadas, nas quais sobejam diferentes instâncias jurídicas de facto geograficamente entrelaçadas, e nas quais abundam fidelidades plurais, suseranias assimétricas (MBEMBE, 
2018). Portanto, motins e matanças selvagens em presídios, com esquartejamentos e degolas, taxações de distribuição de água, transportes, "segurança", construções ilegais, domínios de territórios de áreas públicas para preservação de mananciais, para posterior especulação imobiliária, se tornaram banais, em especial no Rio de Janeiro, São Paulo, Brasília, e em outras grandes cidades, "mecanismos predadores extremamente organizados", máquinas de guerra que já encontram ecos, inclusive nas combalidas "instituições formais" de poder do "Estado Soberano".

Ainda achamos pertinente destacar, jamais deixando de valorar o atual trabalho de Mbembe (2018), que o geógrafo Milton Santos (2009), em sua vasta obra no tocante ao estudo do urbano, pioneiramente (pelo menos no contexto brasileiro, se reporta, ou cria o neologismo necrópole, para ressaltar a profunda fragmentação sócioespacial nas metrópoles brasileiras, $\mathrm{Ou}$ seja, considerando as profundas dissimetrias na feitura das grandes metrópoles no nosso país, o referido autor, se atinou que a metrópole, no sentido grego, como o somatório de metropolis (mãe, ventre) e polis (cidade), polarizadora de inúmeras cidades e seus municípios nos campos políticos, econômicos e culturais, nunca possuíram espírito materno de pertencimento, de civitas, de cidadania. Muito pelo contrário, como hoje, tornaram-se necrópoles, campos de guerra entre pessoas anticivis, segregacionistas, social e territorialmente; lugares onde os estranhos não podem se encontrar, como bem ressalta Bauman (2005). Nesse contexto, em 2019, segundo dados do Depen, (Departamento Penitenciário Nacional), ligado ao Ministério da Justiça, o Brasil detinha mais de 773 mil presos em Unidades Prisionais e nas carceragens de delegacias (agenciabrasil.ebc.com.br). Acirrando ainda mais esse panorama, vem crescendo exponencialmente o número de pessoas no patamar de pobreza extrema. Dados da Síntese de Indicadores Sociais, do IBGE, 6,5\% da população brasileira, em 2018, ou seja, 13, 5 milhões de habitantes se encontravam no referido estágio (agenciadenotícias.ibge.gov.br). Já quando ao desnível de renda, em 2017, os ricos do Brasil ganharam 36,1 vezes mais do que metade dos mais pobres, uma média de $\mathrm{R} \$ 27.213$, enquanto os desvalidos ganhavam $\mathrm{R} \$ 754$ (agenciabrasil.ebc.com.br). Quanto ao acesso à saúde, mais de 100 milhões de pessoas (www1.folha.uol.com.br), na sua maioria com baixos rendimentos financeiros, são assistidas pelo SUS (Sistema Único de Saúde), uma estrutura inclusiva e universal, todavia, desassistida financeiramente, fato que leva seus demandantes a verdadeiras situações de calamidade, em decorrência de déficit de toda uma razoável estrutura médica. Superlotação, carência de equipamentos e técnicos são a palavra de ordem. E agora com a pandemia do convid-19, um 
verdadeiro sentimento de terror tem se alastrado. Quanto às pessoas carentes de trabalho e renda, vale ainda ressaltar, que parte dela vive em 6329 favelas espraiadas em todo o país, lugares insalubres e sujeitos a diversos riscos, como os constantes deslizamento de barreiras, que tanto mata pessoas, em especial em períodos chuvosos. Como diz Wacquant (2007, p.7), são espaços situados na base do sistema hierárquico de regões que compõem uma metrópole, nas quais os párias urbanos residem e onde os problemas sociais se congregam e infeccionam, atraindo a atenção desigual e desmedidamente negativa da mídia, dos políticos e dos dirigentes do Estado. É nesse contexto que cresce o desespero dos marginalizados, ou como fala Morin (2002), as pessoas tendem a cambiar do seu estágio sapiens, para o demens e deste, em muitos casos, para o Killer, como demostra os números de crimes mortes letais e intencionais no Brasil, amtes relatados. Também, e nesta linha, Mbembe (2018, pp. 61-64), destaca o necropoder e a necropolítica do Estado de Israel, frente aos palestinos, e os dois mecanismos de revide desta nação e suas necrópoles: "a "lógica da sobrevivência e a "lógica do martírio"”. Se embasando em Elias Canetti ele frisa que "o sobrevivente é aquele que, tendo percorrido o caminho da morte, sabendo dos extermínios e permanecendo entre os que caíram, ainda está vivo. Ou mais precisamente, o sobrevivente é aquele que, após lutar contra muitos inimigos, conseguiu não só escapar com vida, como também matar seus agressores. Por isso, o grau mais baixo de sobrevivência é matar”. Essas fortes assertivas, talvez explique, em grande medida, os sicários, grupos de extermínio, milícias que se disseminam por nossas metrópoles e seus grandes embates entre si e o Estado de Direito. As consequências: a população sem cidadania e pertencimento, sob o guarda-chuva do aparato repressivo do Estado oficial, fica sob a mira de balas perdidas e, como consequência, em muitos casos, a morte, ou seja, permanecendo entre aqueles que caíram, o que denota um verdadeiro necropoder. Já no que tange a questão do mártírio, "o corpo não esconde apenas uma arma. Ele é transformado em arma, não em sentido metafórico, mas no sentido verdadeiramente balístico": os homens-bombas. No caso brasileiro, seguramente o desespero não tem chegado a esse nível, mas o martírio, parcela expressiva da população, tem assumido a condição de grande sofrimento e aflição, por tudo que foi exposto sob a égide insensível da necropolítica e do necropoder. 


\section{BIBLIOGRAFIA}

AGAMBEn, Giorgio. Homo Sacer. O Poder Soberano e a Vida Nua I. Belo Horizonte: Ed, UFMG, 2004

BAUMAN, Zigmunto. Modernidade Líquida. Rio de Janeiro: Jorge Zahar Editor, 2001

BAUMAN, Zigmunt. Vidas desperdiçadas. Jorge Zahar Editor, 2005

HARVEY, David. Condição Pós-Moderna. São Paulo: Ed. Loyola, 1992.

MBEMBE, Achille. Necropolítica. São Paulo: n-1 edições, 2018

MORIN, Edgar. O Método 5. A Humanidade da Humanidade. Porte Alegre: Sulinas, 2002

RAFFESTIN, Claude. Por uma Geografia do Poder. São Paulo: Ed. Ática, 1983

SÁ, Alcindo José de. Geografia do Direito: as normas como formas sócio-espaciais. Recife: Ed. Universitária da UFPE, 2013

SANTOS, Milton. Pensando o Espaço do Homem. São Paulo: Edusp, 2009

SANTOS, Milton. A Natureza do Espaço. Técnica e Tempo. Razão e Emoção. São Paulo: HUCITEC, 1996

WACQUANT, Loïc. Os Condenados da Cidade. Rio de Janeiro : Revan;FASE, 2001 